\title{
PENGARUH PENGGUNAAN MODUL KONTEKSTUAL BERBASIS MULTIREPRESENTASI PADA PEMBELAJARAN HUKUM GRAVITASI NEWTON TERHADAP HASIL BELAJAR
}

\author{
Siti Mardian Rahayu ${ }^{1 *}$, Chandra Ertikanto ${ }^{2}$, Ismu Wahyudi ${ }^{3}$ \\ FKIP Universitas Lampung, Jl. Prof. Dr. Soemantri Brodjonegoro No. 1 Bandar Lampung \\ *mardianrahayu59@gmail.com
}

Received: 28 Mei 2018

Accepted: 4 Juni 2018

Online Published: 4 Juni 2018

\begin{abstract}
The Effect of Using Contextual Multirepresentation Module on Newton Gravity Law Learning to Student Learning Outcomes. The purpose of this research is to know how the influence of the use of Multi-representation based contextual learning module on Gravity Newton Law study on student learning outcomes in SMA Negeri 1 Padang Cermin. This research was conducted in SMA Negeri 1 Padang Cermin with Pretest-Posttest Control Group Design. The data analysis technique of student learning result using the N-gain score and hypothesis test using Independent T-Test test. Sig value. (2-tailed) by $0.000<0.05$. The results of this study indicate that the use of multi-representation based contextual module has a significant improvement on student learning outcomes, this is indicated by the difference in the average value of $N$-gain in the control class of 0.35 with the low category and the average value of $N$-gain on experimental class 0.64 with a moderate category.
\end{abstract}

Keywords: Student Learning Outcomes, Newton Gravity Law, Multirepresentation-based Contextual Module,

Abstrak: Pengaruh Penggunaan Modul Kontekstual Berbasis Multirepresentasi pada Pembelajaran Hukum Gravitasi Newton Terhadap Hasil Belajar Siswa. Tujuan dari penelitian ini yaitu untuk mengetahui bagaimana pengaruh penggunaan modul konstektual berbasis multirepresentasi pada pembelajaran Hukum Gravitasi Newton terhadap hasil belajar siswa di SMA Negeri 1 Padang Cermin. Penelitian ini dilakukan di SMA Negeri 1 Padang Cermin dengan Pretest-Posttest Control Group Design. Teknik analisis data hasil belajar siswa menggunakan skor $\mathrm{N}$-gain dan pengujian hipotesis menggunakan uji Independent T-Test. Nilai Sig. (2-tailed) sebesar $0,000<0,05$. Hasil penelitian ini menunjukkan bahwa penggunaan modul konstektual berbasis multirepresentasi memiliki peningkatan signifikan terhadap hasil belajar siswa, hal ini ditunjukkan dengan adanya perbedaan rata-rata nilai $\mathrm{N}$-gain pada kelas kontrol sebesar 0,35 dengan katagori rendah dan rata-rata nilai $\mathrm{N}$-gain pada kelas eksperimen 0,64 dengan katagori sedang.

Kata kunci: Hasil Belajar Saiswa, Hukum Gravitasi Newton, Modul Kontektual berbasis Multirepresentasi, 


\section{PENDAHULUAN}

Pendidikan merupakan sesuatu yang memiliki kedudukan sangat penting. Pesatnya perkembangan dunia pendidikan di Indonesia mengalami suatu paradigma baru yang mengusung Kurikulum Berbasis Kompetensi dimana terdapat perubahan sistem pembelajaran konvensional menuju pembelajaran kontekstual. Hamruni (2012: 135), menyatakan pembelajaran kontekstual mengarahkan siswa kepada proses pemecahan masalah, sebab dengan memecahkan masalah anak akan berkembang secara utuh, bukan hanya secara intelektual, tetapi juga mental dan emosionalnya. Pembelajaran kontekstual merupakan pembelajaran yang mengaitkan materi yang dipelajari dengan kehidupan sehari-hari.

Fisika merupakan ilmu yang kompleks dan sangat berkaitan dengan kehidupan sehari-hari. Fisika juga merupakan ilmu pengetahuan alam yang bukan hanya sekedar menerapkan rumusrumus, konsep-konsep, atau prinsipprinsip saja dalam menyelesaikan suatu permasalahan, tetapi semestinya terdapat kegiatan ilmiah di dalam proses pembelajarannya. Kegiatan ini untuk menemukan fenomena alam yang berkaitan dengan fisika secara sistematis. Wangi, dkk. (2015) dalam penelitianya menyatakan bahwa pembelajaran kontekstual mengaitkan materi ajar dengan kehidupan sehari-hari dapat meningkatkan hasil belajar siswa. Siswa dituntut untuk mampu melakuan kegiatan penemuanpenemuan dan dapat memberikan solusi pemecahan dari sebuah masalah yang ditemui berkaitan dengan fisika.

Ilmu fisika masih dianggap pelajaran paling sulit dan menakutkan bagi siswa, faktor penyebab utamanya adalah banyak rumus-rumus matematik dalam fisika, dan siswa ber-anggapan bahwa rumus-rumus tersebut harus dihafal. Padahal fisika merupakan pelajaran yang tidak mengharuskan siswa untuk menghafal rumus matematik yang berkaitan dengan fisika, tetapi seharusnya siswa memiliki kemampuan dalam merepresentasikan suatu permasalahan fisika. Mahardika (2013) menyatakan kebanyakan siswa dalam merepresentasikan suatu permasalahan fisika masih sangat sulit.

Merepresentasikan suatu pembelajaran fisika siswa masih sangat minim (Fatmala, dkk. 2017), siswa hanya dapat menampilkan dua representasi dalam proses pembelajaran yaitu representasi verbal dan matematis, serta konten yang ada di dalamnya kurang bervariasi, sedangkan pembelajaran konsep fisika tidak hanya berupa dua representasi, melainkan banyak representasi yang harus diberikan kepada siswa. Representasi tersebut diantaranya representasi verbal, visual atau gambar, grafik, matematis, dan lain-lain. Selama ini pendidik lebih banyak memberikan representasi matematis, sehingga siswa yang kemampuan matematisnya kurang baik menjadi kesulitan dalam memahami konsep fisika dan mendapat hasil belajar yang kurang maksimal (Sabirin, 2014).

Rendahnya kemampuan multirepresentasi siswa, juga dapat disebabkan oleh kegiatan pembelajaran yang dilakukan oleh guru. Pada umumnya, kegiatan pembelajaran fisika hanya dilakukan dengan metode ceramah dan menulis kemudian siswa diberi tugas berupa soal-soal secara rutin. Pemberian 
tugas berupa soal-soal secara rutin kepada siswa tidak dipastikan dapat meningkatkan kemampuan representasi matematis siswa. Salah satu pendukung berhasil suatu proses pembelajaran kontekstual di sekolah yaitu dengan adanya media pembelajaran berupa bahan ajar. Salah satu contoh bahan ajar yang dapat mendukung kegiatan pembelajaran kontekstual yaitu modul pembelajaran dimana modul pembelajaran ini akan membantu siswa dalam proses pembelajaran baik di kelas maupun di rumah karena modul pembelajaran tidak hanya di gunakan di kelas bias juga untuk belajar sendiri. Modul kontekstual dapat meningkatkan hasil belajar siswa Jaya (2012) dimana dengan mengunakan modul ini biasanya dapat memuat tentang tujuan belajar yang spesifik materi atau substansi belajar, dan evaluasi. Modul merupakan salah satu bentuk bahan ajar yang dikemas secara utuh dan sistematis, di dalamnya memuat seperangkat pengalaman belajar yang terencana dan didesain untuk membantu siswa menguasai tujuan belajar yang spesifik materi atau substansi belajar, dan evaluasi (Depdiknas, 2008: 4).

Modul dalam pembelajaran sangatlah beguna dalam proses pembelajaran karena modul di dikemas secara utuh dan sistematis, di dalamnya memuat seperangkat pengalaman belajar yang terencana dan didesain untuk membantu siswa menguasai tujuan belajar yang spesifik, materi atau substansi belajar, dan evaluasi. Modul sebagai media pembelajaran dengan adanya modul kontekstual berbasis multirepresentasi ini siswa dapat memecahkan soal kedalam bentuk apa pun tidak hanya representasi matematis saja tetapi memuat satu konsep materi yang dapat disampaikan dalam berbagai representasi yaitu representasi verbal, matematik, gambar, grafik, dan di dalam modul mengikuti sintaks contextual teaching and learning.

Modul pembelajaran kontekstual berbasis multirepresentasi untuk mengukur kemampuan nilai kognitif siswa. Modul yang digunakan ini sudah teruji dan tervalidasi dengan modul sangat menarik sekor 3,48 sangat mudah dengan skor 3,42 dan bermanfaat dengan skor 3,10. Maka dengan adanya modul kontekstual berbasis multirepresentasi ini penulis mengimplementasikan bagaimana pe-ngaruh pengunaan modul kontekstual berbaisi multirepresentasi terhadap hasil belajar siswa.

Adapun tujuan dari penelitian ini adalah untuk mengetahui pengaruh penggunaan modul kontekstual berbasis multirepresentasi pada pembelajaran Hukum Gravitasi Newton terhadap hasil belajar siswa

\section{METODE}

Penelitian ini adalah penelitian eksperimen dengan populasi penelitian yaitu seluruh siswa kelas X MIPA di SMA Negeri 1 Padang Cermin pada semester genap tahun ajaran 2017/2018 yang terdiri dari lima kelas. Penentuan sampel pada penelitian ini dilakukan dengan teknik purposive sampling, kelas yang digunakan sebagai sampel adalah kelas X MIPA 3 dengan jumlah 36 siswa sebagai kelas eksperimen dan X MIPA 4 dengan jumlah 36 siswa

Penelitian ini mengunakan desain penelitian Pretest-Posttest Control Group Design. Pada kelas eksperimen diberikan perlakuan dengan menggunakan Modul kontekstual berbasis multirepresentasi, sedangkan kelas kontrol menggunakan buku siswa dari sekolah selanjutnya diobservasi hasil belajarnya. Pada 
penelitian ini terdapat dua macam variabel yaitu variabel bebas dan variabel terikat. Variabel bebas dalam penelitian ini adalah penggunaan modul kontekstual berbasis multirepresentasi, sedangkan variabel terikatnya adalah hasil belajar siswa. Secara umum desain penelitian dapat dilihat pada Gambar 1.

\begin{tabular}{|ccc|}
\hline $\mathrm{O}_{1}$ & $\mathrm{X}_{1}$ & $\mathrm{O}_{2}$ \\
$\mathrm{O}_{3}$ & $\mathrm{X}_{2}$ & $\mathrm{O}_{4}$ \\
\hline
\end{tabular}

Gambar 1. Pretest-Posttest Control Group Design

Langkah-langkah dari penelitian ini yaitu menetapkan sempel penelitian selanjutnya, melakukan penilaian terhadap hasil belajar siswa pada ranah kognitif melalui pretest, melaksanakan proses pembelajaran dengan menggunakan modul pembelajaran konstrektual berbasis multirepresentasi materi Hukum Gravitasi Newton, mengadakan posttest pada akhir pembelajaran untuk mengetahui dan memperoleh data mengenai hasil belajar siswa pada ranah kognitif, menilai hasil posttest untuk mengetahui perubahan hasil belajar siswa, menganalisis hasil belajar mengenai pengaruh penggunaan modul konstrektual berbasis multirepresentasi pada pembelajaran Hukum Gravitasi Newton terhadap hasil belajar pada ranah kognitif siswa.

Instrumen yang digunakan dalam penelitian ini adalah Rencana Pelaksanaan Pembelajaran (RPP), modul pembelajaran kontekstual berbasis multirepresentasi dan lembar sol tes hasil belajar. Sebelum instrumen digunakan dalam sampel, instrumen diuji terlebih dahulu dengan uji validitas dan uji reliabilitas. Pengumpulan data pada penelitian ini dilakukan pada saat sebelum dan setelah kegiatan pembelajaran di kelas control dan kelas eksperimen dari kegiatan pretest dan posttest. Data dalam penelitian ini bersifat kuantitatif yaitu data hasil belajar siswa pada ranah kognitif. Uji yang dilakukan terhadap data tersebut yaitu Uji Normalitas, Uji Homogenitas, Uji $N$-Gain, dan Uji Independent Sample T-Test. Data hasil belajar siswa dianalisis menggunakan data $N$-Gain yang ternormalisasi.

Uji normalitas dilakukan terhadap data pretest dan data posttest hasil belajar siswa, yang telah didapat dari hasil pembelajaran pada kelas kontrol dan kelas eksperimen. Kemudian dilakukan uji homogenitas untuk melihat kedua kelas mempunyai varians yang sama. Pada penelitian ini, uji normalitas yang digunakan adalah uji KolmogrovSmirnov. Data dikatakan memenuhi asumsi normalitas atau terdistribusi normal jika pada Kolmogorov-Smirnov nilai sig. $\geq 0.05$ sebaliknya data yang nilai sig. $\leq 0.05$ tidak terdistribusi normal. Untuk melihat uji homogenitas menggunakan uji fister dengan kriteria uji adalah jika signifikansi >0,05 maka kedua data varians adalah homogen.

Setelah dilakukan uji normalitas, selanjutnya dilakukanlah uji Independent Sample T-Test. Uji ini dilakukan untuk membandingkan dua sampel yang berbeda (bebas) Independent Sample T-Test digunakan untuk mengetahui ada atau tidaknya peningkatan rata-rata antara dua kelompok sampel yang tidak berhubungan. Analisis tersebut digunakan untuk mengetahui diterima atau tidaknya hipotesis yang telah dibuat. Kriteria pengujiannya yaitu jika probabilitas (Asymp.Sig) $\leq 0,05$, maka Ho ditolak dan jika probabilitas (Asymp.Sig) $\geq 0,05$, 
maka Ho diterima.

\section{HASIL DAN PEMBAHASAN}

Penelitian ini mengenai pengaruh penggunaan modul kontekstual berbasis multirepresentasi dalam pembelajaran fisika materi Hukum Gravitasi Newton terhadap hasil belajar siswa SMA Negeri 1 Padang Cermin ini mulai dilaksanakan pada hari Senin 12 Februari 2018. Proses pembelajaran berlangsung selama empat kali tatap muka dengan alokasi waktu 3 jam pelajaran yang terdiri atas 45 menit per jam pelajaran. Tes evaluasi pembelajaran dilaksanakan di luar jam pelajaran. Hasil yang diperoleh dari penelitian ini berupa data kuantitatif.

Penelitian ini menggunakan kelas $\mathrm{X}$ MIPA 3 di SMA Negeri 1 Padang Cermin sebagai kelas eksperimen Pelaksanaan pembelajaran pada kelas ini diikuti oleh 36 siswa dan dilakukan menyesuaikan jadwal pelajaran fisika di sekolah, yaitu setiap hari Senin pukul 11.05 WIB sampai dengan pukul 14.00 WIB. Pembelajaran berlangsung dari tanggal 12 Februari 2018 sampai tanggal 5 Maret 2018. Keseluruhan proses pembelajaran sebanyak empat kali pertemuan dan satu kali pertemuan untuk test evaluasi pembelajaran. Pembelajaran dilaksanakan selama tiga jam pelajaran dengan alokasi waktu 3 x 45 jam pelajaran dan sama untuk setiap pertemuan. Pembelajaran pada kelas eksperimen menggunakan modul kontekstual berbasis multirepresentasi yang telah dibagikan kepada masing-masing siswa.

Penelitian ini menggunakan kelas $\mathrm{X}$ MIPA 4 di SMA Negeri 1 Padang Cermin sebagai kelas kontrol Pelaksanaan pembelajaran pada kelas ini diikuti oleh 36 siswa dan dilakukan menyesuaikan jadwal pelajaran fisika di sekolah, yaitu setiap hari Jumat pukul 09.00 WIB sampai dengan pukul 11.15 WIB. Keseluruhan proses pembelajaran sebanyak empat kali pertemuan dengan alokasi waktu 3 x 45 menit dan sama untuk setiap pertemuan. Satu kali pertemuan untuk evaluasi pembelajaran yang dilakukan di luar jam pelajaran. Pembelajaran berlangsung dari tanggal

16 Februari 2018 sampai tanggal 9 Maret 2017. Pembelajaran pada kelas kontrol menggunakan buku siswa yang digunakan di SMA Negeri 1 Padang Cermin. Data hasil belajar siswa diperoleh dengan memberikan 15 butir pertanyaan pilihan jamak. Peningkatan hasil belajar siswa diperoleh dari skor $N$-gain yang dihitung dari skor pretest dan skor posttest.

Tabel 1. Perolehan N-Gain

\begin{tabular}{cccc}
\hline Kelas & $\begin{array}{c}\text { Pre- } \\
\text { test }\end{array}$ & $\begin{array}{c}\text { Post- } \\
\text { test }\end{array}$ & $\begin{array}{c}N- \\
\text { gain }\end{array}$ \\
\hline Eksperimen & 41,25 & 79,50 & 0,64 \\
Kontrol & 45,48 & 64,23 & 0,35 \\
\hline
\end{tabular}

Tabel 1 memperlihatkan bahwa perolehan $\mathrm{N}$-Gain kelas eksperimen sebesar 0,64 dengan kategori sedang lebih tinggi dari pada kelas kontrol dengan perolehan $\mathrm{N}$-Gain sebesar 0,35 dengan kategori rendah. Sehingga kelas eksperimen yang menggunakan modul kontekstual berbasis multirepresentasi memperoleh peningkatan hasil belajar yang lebih tinggi dibanding kelas kontrol yang menggunakan buku siswa yang dipakai di sekolah pada proses pembelajaran.

Tabel 2. Uji Normalitas Data Hasil Belajar kognitif

\begin{tabular}{ccc}
\hline No & Kelas & $\begin{array}{c}\text { Kolmogrov } \\
\text { Smirnov Sig }\end{array}$ \\
\hline 1 & Eksperimen & 0,200 \\
2 & Kontrol & 0,200 \\
\hline
\end{tabular}


Tabel 2 meperlihatkan bahwa data nilai rata-rata hasil belajar siswa berdistribusi normal dengan nilai Asymp. Sig. (2-tailed) di atas 0,05 yaitu 0,200 untuk kelas eksperimen dan kelas kontrol. Berdasarkan hasil uji normalitas maka diperoleh bahwa data nilai hasil belajar ranah kognitif dari kelas eksperimen dan kelas kontrol berdistribusi normal

Selanjutnya dilakukan Uji homogenitas didapatkan nilai Sig pada kelas eksperimen dan kelas control samasama 0,200 maka menunjukkan bahwa nilai signifikansi dari uji kesamaan varian (homogenitas), karena signifikansi lebih dari 0,05 maka diperoleh bahwa kedua varian sama (varian kelompok kelas eksperimen dan kelas kontrol adalah sama).
Setelah di dapat nilai uji Normalitas dan uji homogenitas selanjutnya dilakukan uji hipotesis dimana untuk melakukan uji hipotesis di terima atau di tolaknya hipotesis dilakukan uji Independent Sample T-Test seperti yang terlihat pada tabel 4

Tabel 4 memperlihatkan bahwa penggunaan uji $\mathrm{T}$ menggunakan Equal variances assumed, karena nilai Asymp. Sig. (2-tailed) pada uji t adalah sebesar 0,000 kurang dari 0,05 maka diperoleh bahwa $H_{0}$ ditolak dan $H_{1}$ diterima. Maka hasil pengujian tersebut dapat diperoleh bahwa. "terdapat pengaruh penggunaan modul kontekstual berbasis multirepresentasi pada pembelajaran hukum gravitasi newton terhadap hasil belajar siswa di SMA Negeri 1 Padang Cermin ".

Tabel 4 . Hasil Uji Independent Sample t-test

\begin{tabular}{lcccccc}
\hline \multicolumn{1}{c}{ Varians } & \multicolumn{2}{c}{$\begin{array}{c}\text { Levene's Test for } \\
\text { Equality of Variances }\end{array}$} & \multicolumn{2}{c}{$\begin{array}{c}\text { t-test for Equality } \\
\text { of Means }\end{array}$} \\
\cline { 2 - 6 } & $\mathrm{F}$ & Sig. & $\mathrm{T}$ & $\mathrm{Df}$ & $\begin{array}{c}\text { Sig. (2- } \\
\text { tailed) }\end{array}$ \\
\hline Equal variances assumed & 2.771 & .100 & 6.408 & 70 & .000 \\
Equal variances not assumed & & & 6.408 & 64.269 & .000 \\
\hline
\end{tabular}

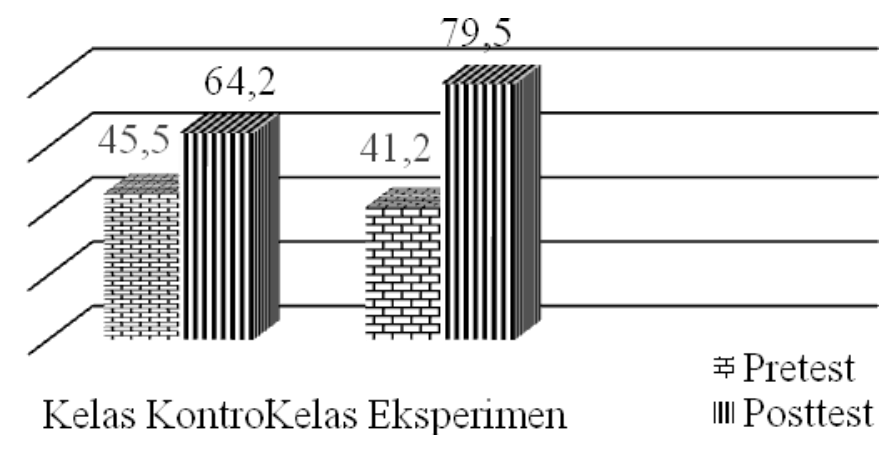

Gambar 2. Grafik Perbandingan Rata-rata Nilai Pretest dan Posttest Hasil Belajar Kedua Kelas 


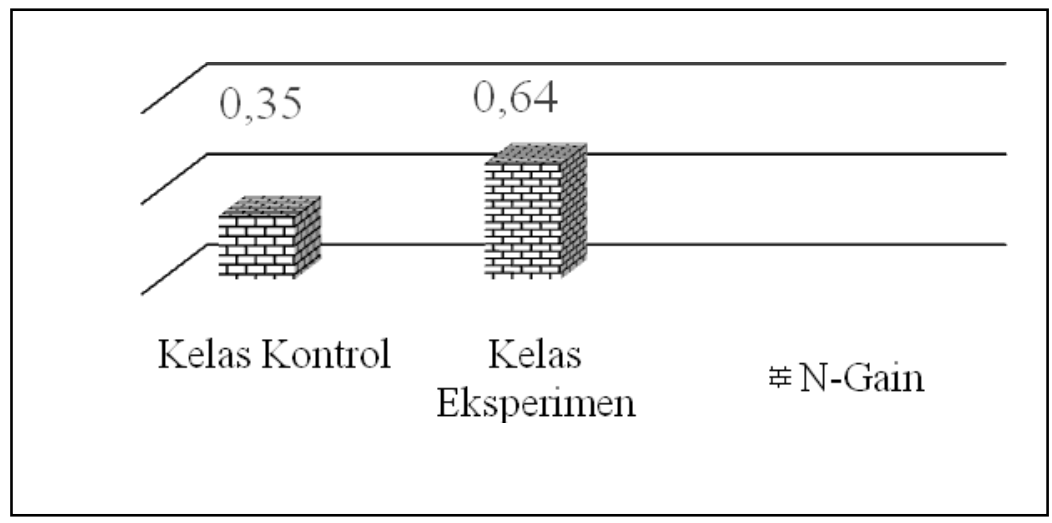

Gambar 3. Grafik Perbandingan Nilai N-gain Hasil Belajar

Kelas Eksperimen dan Kelas Kontrol

Gambar 2 dapat diketahui bahwa nilai pretest siswa kelas konstrol sebesar 45,8 lebih tinggi dari pada rata-rata nilai pretest kelas eksperimen sebesar 41,2. Setelah di-lakukan proses pembelajaran kelas eksperimen mengunakan modul konteksual berbasis multirepresentasi materi hokum gravitasi newton hasil belajar siswa rata-ratanya sebesar 79,5 meningkat lebih besar dari kelas kontrol yang mengunakan buku teks yang biasa digunakan di kelas memiliki nilai rata-rata hasil belajar sebesar 64,2.

Gambar 3 tersebut, rata-rata $N$-Gain hasil belajar siswa pada kelas eksperimen lebih besar dari pada ratarata hasil belajar siswa pada kelas kontrol. Kelas kontrol yang menggunakan buku siswa dari sekolah, diketahui rata-rata $N$-Gain hasil belajar siswa sebesar 0,35 (kategori rendah). Kelas eksperimen dengan menggunakan modul konstektual berbasis multirepresentasi materi hukum gravitasi newton memiliki rata-rata $N$-Gain 0,64 dengan (katagori sedang)

\section{PEMBAHASAN}

Berdasarkan penelitian yang telah dilakukan rata-rata $N$-Gain hasil belajar siswa pada kelas eksperimen lebih besar dari pada rata-rata hasil belajar siswa pada kelas kontrol. Kelas kontrol yang menggunakan buku siswa dari sekolah, diketahui rata-rata $N$-Gain hasil belajar siswa sebesar 0,35 (kategori rendah). Kelas eksperimen dengan menggunakan modul konstektual berbasis multirepresentasi materi hukum gravitasi newton memiliki rata-rata $N$-Gain 0,64 dengan (katagori sedang).

Pada pembelajaran di dalam kelas terjadi dengan sanggat terarah sesuai dengan tahapan yang ada pada modul. Masing-masing siswa dengan mudah dapat mencoba langsung setiap menu dalam modul pembelajaran karena modul ini sudah dilengkapi dengan penunjuk penggunaan yang memudahkan siswa untuk belajar mandiri dengan mengunakan modul pembelajaran ini dapat meningkatkan hasil belajar siswa. Hal ini didukung oleh pendapat Sujanem, dkk. (2009) yang menyatakan bahwa hasil 
belajar yaitu kemampuan-kemampuan yang dimiliki peseta didik setelah ia menerima pengalaman belajar.pemberian modul akan lebih efektif dalam proses pembelajaran hal ini sesuai dengan pendapat Parmin (2012) dan Ardi (2015) dalam penelitianya berpendapat bahwa setelah modul dibagikan kepada siswa maka hasilnya akan lebih efektif karena siswa dapat membaca dan mempelajari leluasan di rumah. Dampak nyata yang telah di rasakan bahwa peran aktif siswa ketika pembelajaran sangat terlihat, ketika guru mengajukan pertanyaan direspon oleh siswa dengan baik dan memberikan ide untuk menyelesaikan permasalahan.

Hasil Uji Indipendent Sampel t-test dapat dikatakan bahwa rata-rata hasil belajar siswa yang menggunakan modul konstektual berbasis multirepresentasi pada materi hukum gravitasi newton lebih tinggi dibandingkan dengan ratarata hasil belajar siswa yang mengunakan buku dari sekolah, artinya terdapat pengaruh pengunaan modul konstektual berbasis multirepresentasi pada pembelajaran materi hukum gravitasi newton terhadap hasil belajar siswa. Perbedaan rata-rata hasil belajar pada masingmasing kelas dapat dilihat dari proses pembelajaran yang diberikan dikelas.

Kelas eksperimen diberikan perlakuan pembelajaran dengan menggunakan modul konstektual berbasis multirepresentasi yang memiliki banyak kelebihan, mempermudah siswa dalam proses pembelajaran. Tingginya hasil belajar di sebebkan pada materi fisika yang diajarkan, karena pembelajaran mengunakan konstektual itu memberikan latihan aktifitas belajar yang berkaitan dengan kehidupan sehari-hari. Hal ini sesuai dengan penelitian yang relevan yang dilakuka Asfiah (2013) pengunaan modul konstektual dapat membantu siswa mengaitkan materi dengan ke-hidupan nyata sehingga siswa mendapat motivasi untuk belajar dan modul yang di padukan dapat membantu siswa dapat menambah pengetahuan yang luas. Penelitian Said \& Jafar (2015) dalam penelitianya menyatakan bahwa hasil belajar siswa mengunakan modul konstektual dapat mencapai ketuntasan belajar siswa. Hal ini selajan dengan pendapat Lestari (2017) dalam penelitianya berpendapat dengan menggunakan pembelajaran kontekstual dapat meningkatkan hasil belajar yang signifikan maka prestasi belajar siswa akan meningkat. Dimana Pembelajaran konstektual merupakan konsep belajar mengajar yang membantu guru menggaitkan antara materi yang diajarkan dengan situasi dunia nyata siswa atau dalam kehidupan sehari-hari serta menggarahkan siswa untuk dapat memecahkan suatu permasalahan yang dapat mengembangkan intelektual, mental yang dapat diterapkan dalam kehidupan seharihari.

Selain mengunakan pembelajaran konstektual modul ini dilengkapi dengan pembelajaran berbasis multirepresentasi yang dapat memudahkan siswa memahami konsep fisika mengenai hukum gravitasi newton dengan berbasis representasi seperti verbal, matematis, gravik dan gambar, sehingga siswa dapat dengan mudah menjelaskan permaslahan fisika yang dihadapi. Materi yang disajikan dalam modul ini dilengkapi dengan representasi akan memudahkan siswa untuk berimajinasi mengenai fenomena yang disajikan. Pada multirepresentasi tujuan memecahkan soal fisika dengan multirepresentasi proses melalui beberapa seperti gambar, verbal, matematis dan grafik. Dengan ke- 
mampuan siswa dapat merepresentasikan sebuah permasalahan fisika maka siswa akan dapat meningkatkan hasil belajar siswa hal ini sesuai dengan yang diungkapkan dengan Abdurahman, dkk. (2011) dalam penelitianya berpendapat bahwa pembelajaran dengan berbasis multirepresentasi dapat meningkatkan hasil belajar siswa dan pemahaman konsep fisika yang signifikan. Hal ini sejalan dengan pendapat Sutari (2014) dan Pratiwi (2017) dalam penelitianya berpendapat bahwa penggunaan multirepresentasi yang baik akan meningkatkan hasil belajar siswa. Teori yang sama juga diungkapkan Tsani dalam Ertikanto,dkk (2018) pada penelitianya menunjukkan bahwa penggunaan representasi untuk meng-komunikasikan ide-ide yang dapat me-ningkatkan pemahaman konsep dan berdasarkan Sabirin (2014) kemampuan representasi sangatlah berguna sebagai sarana mengkomunikasikan gagasan atau ide-ide kepada siswa lain maupun kepada guru.

Beberapa keungulan modul pembelajaran konstektual berbasis multirepresentasi itulah yang memudahkan siswa menyelesikan persoalan yang mengharuskan siswa memahami konsep dengan beberapa representasi. Dikelas kontrol pembelajaran tidak disajikan dalam multirepresentasi, sehingga siswa sulit untuk menjelaskan persoalan yang diberikan. Seperti soal yang menuntut

\section{DAFTAR RUJUKAN}

Abdurahman., Liliasari., Rusli A., \& Waldrip B. 2011. Implementasi Pembelajaran berbasis Multi Representasi untuk peningkatan Penguasaan Konsep Fisika siswa membaca grafik dan gambar, siswa kelas eksperimen rata-rata bisa menjawab dengan benar, sedangkan di kelas kontrol banyak siswa yang tidak menjawab soal tersebut.

Modul ini dikatakan modul yang sangat efektif dalam proses pembelajaran serta berpengaruh dalam peningkatan hasil belajar siswa pada ranah kognitif. Karena siswa dapat belajar secara mandiri di rumah sehingga siswa dapat belajar lebih mendalam dan dapat dijadikan sebagai bahan ajar untuk mningkatkan hasil belajar siswa. Modul ini juga digunakan untuk mengajarkan siswa multirepresentasi, sehingga siswa dapat dengan mudah dan terbiasa menyelesikan persoalan fisika beberapa representasi.

\section{SIMPULAN}

Berdasarkan hasil penelitian dan pembahasan yang telah dilakukan, maka dapat disimpulkan bahwa: Terdapat pengaruh penggunaan modul kontekstual berbasis multirepresentasi yang ditunjukkan dengan perbedaan peningkatan rata-rata hasil belajar siswa dimana perolehan skor rata-rata $N$-Gain hasil belajar siswa pada kelas eksperimen sebesar 0,64 dengan kategori sedang, sedangkan kelas kontrol dengan perolehan skor rata-rata $N$-gain hasil belajar siswa sebesar 0,35 dengan kategori rendah.

.(Online). Kuantum. Cakrawala Pendidikan. Volume 1, No 1. 3034.Tersedia di (https:// jurnal .uny.ac.id/ indeks.phtp/ cp/ article/ 
iew/4189/pdf.), diakses pada tanggal 1 November 2017

Ardi, Nyeneng, P. D. I., Ertikanto C. 2015. Pengembangan Modul Pembelajaran Fisika Berbasis Inkuiri Terbimbing Pada Materi Pokok Suhu dan Kalor. (Online) Jurnla Pembelajaran Fisika Volum 3, No 3 : 64-65. Tersedia di (http:// jurnal. fkip. unila. ac.id/ index .php/JPF/article/view/8571/5305.) diakses pada 12 Mei 2018

Asfiah, Nailin, \& Monsik. 2013 Pengembangan Modul Konstektual IPA Terpadu Pada Tema Bunyi. (Online). Unnes Science Edu-cation Jurnal. Volume 2, No. 1, 188-195. Tersedia di (http/ /journal. unnes.ac.id /artikel_sju/ usej/1822), diakses pada 13 November 2017.

Ertikanto, C., RosidinU., Distrik I.W., Yuberti, \& Rahayu T. 2018. Comparison of Mathematical Representation Skill and Science Learning Resuk in Classes with Problrm-Besed and Discovey Learning Model. (Online), Jurnal Pendidikan IPA Indonesia. Volume 7, No 2. 106-113. Tersedia di (http://jurnal .unnes.ac .id/nju /index. php/jpii article /view9512/7630), diakses pada 15 April 2018.

Depdiknas. 2008. Penulisan Modul. Jakarta: Dirjen PMPTK.

Fatmala, N.T., Nyeneng, P. D. I., \& Suane, W. 2017. Pengembangan modul pembelajaran kontekstual berbasis multirepresentasi pada materi hukum Newton tentang gravitasi. (Online), Jurnal Pendidikan Fisika Volume 5, No 4 : 2123 Tersedia di (http// jurnal. fkip.unila.ac.id /index. php/ JPF/ article/view/13141), Diakses pada 14 september 2017.

Hamruni. 2012. Strategi Pembelajaran. Yogyakarta: Insan Madani

Jaya, 2012. Pengembangan Modul Fisika Konstektul untuk Me-ningkatkan Hasil Belajar Peserta didik kelas X Semester 2 di SMK Negeri 3 Singaraja. . (Online), Jurnal Teknologi Pem-belajaran. Volume 1, No2: 2-5. Tersedia di (http:// www. neliti. com/ publ ication/207153), diakses pada tanggal 22 Januari 2018.

Lestari, D.A. 2017. Pengaruh Pengunaan Model Pembelajaran Contextual Teaching And Lear-ning Type Course Review Horay Terhadap Perestasi Belajar IPA Siswa Kelas IV SD Negeri 1 Mar-ga Agung Kabupaten Lampung Selatan Tahun Pelajaran 2006 /2007. Jurnal Ilmu Pendidikan. (Online), Volume 1, No 1 22-23. Tersedia di (http: //jurnal. fkip. unila.ac. id/ indekx.php/JPF /articele/download/12850/9171), diakses pada 15 April 2018

Mahardika, I. K. 2013. Penerapan Model Pembelajaran Interaktif Berbasis Konsep untuk Me-ningkatkan Kemampuan Rep-resentasi Verbal, Matematik, dan Gambar Fisika Siswa Kelas VIII-A MTs N 1 
Jember Tahun Pelajaran 2012/2013. (Online), Jurnal Pendidikan Fisika, Volume 2, No 3: 272-277. Tersedia di (http:// unej. ac.id/ handle/ $123456789 / 4290$ ), siakses pada 12 November 2017.

Parmin.,\& Peniati E. 2012 Pengembangan Modul Matakuliah Strategi Belajar Mengajar IPA Berbasis Hasil Penelitian Pembelajaran. (Online), Jurnal Pendidikan IPA Indonesia. Volume1, No 1. 1-8. Tersedia di (http://www. gogle.co.id/ media .neliti.com /121261-ID pengembangan-modul-mata-kuliahstrategi.pdf), diakses pada 21 Januari 2018.

Pratiwi, R.I., Nyeneng, P. D. I., Wahyudi I. 2017. Pengembangan Modul Pembelajaran Kontekstual Berbasis Multipe Representations pada Materi Fluida Statis. (Online), Jurnal Pendidikan Fisika Volume 5, No. 3 :69-79. Tersedia di (http://jurnal.fkip.unila.ac.id/index.p hp/JPF/article/view/12850/9171) diakses pada 12 Mei 2018.

Sabirin, M. 2014. Representasi dalam Pembelajaran Matematika. Jurnal Pendidikan Matematika IAIN Antasari. 1 (2): 33-34. (Online), Tersedia di (http:/ media. neliti. Com /media /publication/ 121557 ID-representasidalampembelajaranmatematik),diakses pada 21 Januari 2018.

Said, Gigih, A.,\& Jafar. 2015. Pengunaan Modul Berbasis Konstektual
Terhadap Hasil Belajar Fisika Peserta Didik Pada Pokok Bahasan Hukum Newton Kelas VII MTS Madani Alauddin Paopao. (Online), Jurnal Pen-didikan Fisika.Volume 3, No 2 143-148. Tersedia di (http:/ /journal- alauddin.ac.id/ indeks .php/pendidikanfisika), diiakses pada 22 Januari 2018.

Sujanem, Rai., Suwindra, Putu, I.N., dan Tika, Ketut I. 2009. Pe-ngembangan Modul Fisika Kontekstual Interaktif Berbasis Web untuk Meningkatkan Pe-mahaman Konsep dan Hasil Belajar Fisika Siswa SMA di Singaraja. (Online), Jurnal Pendidikan dan Pengajaran Universitas Pendidikan Ganesha Volume 42,No.2 97-104. Tersedia di (http// pti.undiksha.ac.id), diakses pada 4 November 2017.

Sutari, Tri Aisyah. 2014. Pengaruh Penggunaan Multirepresentasi terhadap Hasil Belajar Fisika di SMA Negeri 5 Banda Aceh tahun Ajaran 2013/2014. (Online), Jurnal Fisika Edukasi, Volume1, No 1, 111. Banda Aceh : Universitas Syiah Kuala. Warsita, Bambang. 2008. Teknologi. Tersedia di (http/ letd. Unsyiah .ac.id/ index.php?p= show_detail \&id=11990), diakses pada 12 November 2017.

Wangi,S.R., Winarti E.R., Kharis M. 2015. Penerapan Model Pembelajaran CTL dengan Strategi REACT untuk Meningkatkan Hasil Belajar Siswa dan Ke-disiplinan Siswa pada Materi Geometri. (Online), Unnes Jurnal of Matehematics Education. Volume 4, 
No 3. 1-7. Tersedia di (http:/ /1 ib.unnes. ac.id/ 22 295/ 1/ 4101 411187-s.pdf). diakses pada 21 Januari 2018. 